\title{
Legalitas Peresmian Akta Notaris Berbasis Cyber Notary Melalui Media Konferensi Zoom
}

\author{
I Dewa Gede Cahaya Dita Darmaangga1, I Dewa Ayu Dwi Mayasari²
}

${ }^{1}$ Fakultas Hukum Universitas Udayana, Email : cahayafh2@gmail.com

${ }^{2}$ Fakultas Hukum Universitas Udayana, Email : dewaayudwimayasari@gmail.com

\begin{abstract}
Info Artikel
Masuk : 21 Januari 2021

Diterima : 25 Januari 2021

Terbit : 1 April 2021

Keywords :

Inauguration, Cyber Notary,

Zoom Application

Kata kunci:

Peresmian, Cyber Notary.

Aplikasi Zoom

Corresponding Author:

I Dewa Gede Cahaya Dita

Darmaangga, E-mail:

cahayafh2@gmail.com

DOI :

10.24843/AC.2021.v06.i01.p16
\end{abstract}

\begin{abstract}
This study aims to find out about the legality of the inauguration of cyber-based notary deeds through the Zoom Conference media and the legal consequences of notarial deeds inaugurating the Zoom Conference media. The research method used is normative legal research methods that use a statutory approach and analysis of legal concepts based on primary and secondary legal materials. The study result show that according to Article 1868 of the Civil Code stipulates that the making of an authentic deeds is made is the presence of an authorized public official. Homeever, when referring to the explanation of Article 15 paragraph (3) of Law Number 2 of 2014 concerning the Position of Notary Public, there is no clarity regarding the explanation regarding electronic certification (cyber notary) whether tappers must remain physically present in front of a notary or may not ignore it virtually. Regarding the inauguration of deeds through the Zoom Conference media, its is necessary to have clearer regulations regarding the concept of cyber notary in the world of notary so that notaries can carry out their duties without violating laws and regulations. The concept of cyber notary, in the inauguration of the deed, it is felt that there is a need for regulations that clearly regulate how the terms or conditions in the inauguration of authentic deeds/notaries are carried out using the concept of cyber notary, one of which is the Zoom Cenference media.
\end{abstract}

\footnotetext{
Abstrak

Studi ini bertujuan untuk mengetahui mengenai legalitas peresmian akta Notaris berbasis cyber notary melalui media Konferensi Zoom dan akibat hukum peresmian akta otaris dilakukan dengan media Konferensi Zoom. Metode penelitian yang digunakan yaitu dengan metode penelitian hukum normatif yang menggunakan pendekatan perundang-undangan serta analisis konsep hukum dengan bersumber pada bahan-bahan hukum primer maupun sekunder. Hasil studi menunjukan bahwa menurut Pasal 1868 KUHPerdata menentukan mengenai pembuatan akta otentik tersebut dibuat dihadapan pejabat umum yang berwenang. Tetapi apabila merujuk terhadap penjelasan Pasal 15 ayat (3) Undang-Undang Nomor 2 Tahun 2014 Tentang Jabatan Notaris tidak ada kejelasan mengenai penjelasan mengenai sertifikasi elektronik (cyber notary) apakah para
} 


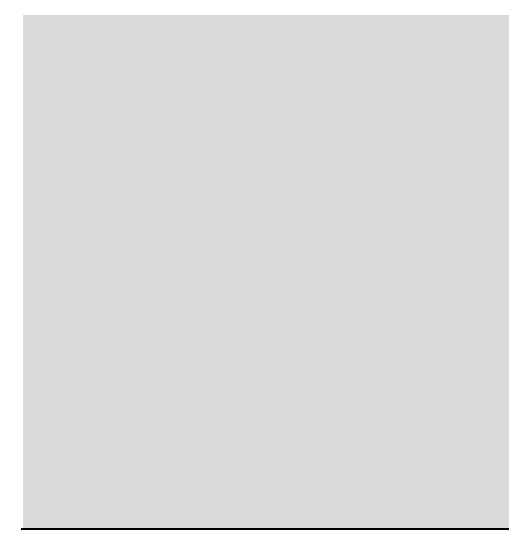

penghadap harus tetap hadir secara fisik dihadapan notaris ataukah boleh tidak melaikan secara virtual. Terkait dengan peresmian akta melalui media Konferensi Zoom maka diperlukan adanya pengaturan lebih jelas mengenai konsep cyber notary dalam dunia kenotariatan agar notaris dapat menjalankan tugas jabatannya tanpa menyalahi undang-undang dan peraturan perundang-undangan. Konsep cyber notary ini dalam peresmian akta dirasa perlunya ada pengaturan yang mengatur dengan jelas bagaimana ketentuan atau syarat dalam peresmian akta autentik/notaris yang dilakukan dengan menggunakan konsep cyber notary salah satunya adalah media Konferensi Zoom.

\section{Pendahuluan}

Perkembangan teknologi yang semakin pesat di Indonesia dapat membuat perubahan sangat signifikan diberbagai bidang. Perkembangan teknologi membuat berbagai keperluan kehidupan dapat dilaksanakan dengan berbagai kemudahan-kemudahan yang ada. Perlahan namun pasti transaksi jual beli akan bergeser dari jual beli secara konvensional menjadi berbasis elektronik, maka kini dikenal e-Commerce. Selain itu di lini penyelenggaraan pemerintah khususnya pelayanan pulik juga tengah mengedepankan pelayanan yang berbasis elektronik. ${ }^{1}$ Notaris sebagai seorang pejabat umum yang senantiasa melayani seluruh masyarakat pun harus mengikuti perkembangan teknologi yang semakin maju dan berkembang mengikuti perkembangan teknologi seperti halnya media Konferensi atau telekomprensi. Di berbagai Negara yang menganut sistem common law maupun civil law dan Indonesia sekalipun telah mengenal mengenai transaksi elektronik dalam lembaga kenotariatan atau yang lebih dikenal dengan sebutan cyber notary. Indonesia harus menstimulus perkembangan penyelenggaraan peran dan fungsi Notaris dalam menjalankan transaksi elektronik, bahkan dengan pelayanan jasa terhadap bidang kenotariatan itu secara elektronik.

Nobert Wienercyber menyebutkan bahwa kata cybernetic merupakan perpaduan bidang ilmu antara computer, elector, matematika dan psikologi. Cyber tersebut menyangkut halhal komputerisasi yang sebagai media elektronik atau dalam dunia maya (cyberspace) yang digunakan untuk melakukan komunikasi antara satu arah atau melakukan hubungan timbal balik secara online. Notaris dalam memberikan pelayanan jasa dibidang transaksi elektronik juga diharapkan memberikan kecepatan, ketepatan waktu dan efisiensi yang biasanya sangatlah diperlukan atau dibutuhkan oleh para pihak. ${ }^{2}$ Para penghadap tidak menghadap langsung (fisik) atau berhadapan-hadapan dengan Notaris secara langsung di kantornya, para penghadap bisa saja berada disuatu wilayah yang berbeda atara satu sama lain yang berbeda dengan kedudukan wilayah jabatan Notaris tersebut.

\footnotetext{
1 Setiadewi, K., \& Wijaya, I. M. H. (2020). Legalitas Akta Notaris Berbasis Cyber Notary Sebagai Akta Otentik. Jurnal Komunikasi Hukum (JKH), 6(1), 126-134. h. 127

2 Makarim, E. (2013). Notaris dan Transaksi Elektronik; Kajian Hukum Tentang Cyber Notary atau

Electronic Notary. Jakarta: PT Raja Grafindo Perkasa. h. 117
} 
Cyber Notary merupakan "sebuah konsep yang menggunakan dan memanfaatkan perkembangan adanya kemajuan akan teknologi dalam hal para notaris dalam membuat sebuah akta autentik dan menjalankan tugasnya sehari-hari. Misalnya dalam proses penandatanganan akta yang dilakukan secara elektronik dan rapat umum pemegang saham yang dilakukan secara teleconference". ${ }^{3}$ Cyber Notary dianggap mempercepat atau memudahkan dalam menjalankan tugas-tugasnya dan kewenangan yang dimilikinya seperti halnya membuat sebuah akta autentik dalam suatu perbuatan hukum, perjanjian, dan ketetapan yang memang diharuskan dalam Undang-undang dan hal-hal telah dikehendaki oleh para penghadap/para pihak yang memiliki kepentingan untuk nantinya dinyatakan dalam sebuah akta autentik.

Perkembagan teknologi yang membuat masyarakat harus terus beradaptasi dengan kemajuan teknologi mendorong berbagai invoasi-inovasi dalam hal teknologi Konferensi. Kemajuan teknologi ini menguntungkan manusia karena dapat mempermudah pekerjaan yang harus dilakukannya sehari-hari. Salah satu perkembangan teknologi yang kini sudah sering kita dengar dan digunakan oleh masyarakat luas adalah media Konferensi yang menampilkan video. Kemajuan media Konferensi tersebut sangat membantu pekerjaan manusia karena dapat dilaksanakan dengan cepat tanpa memperhitungkan jarak antara penggunannya. Salah satu media telekomuniasi video tersebut adalah Zoom. Dimana dengan media Zoom para pihak dapat berkomunikasi secara langsung dengan menampilkan video kondisi terkini di keberadaan masing-masing.

Media Konferensi Zoom merupakan sebuah layanan video konferensi yang berbasis pada cloud computing. Dengan Zoom membuat seseorang dapat bertemu dengan orang lain secara virtual dengan cara panggilan suara dan panggilan video anatara satu orang dengan orang lainnya secara waktu yang bersamaan (real time). Selain itu percakapan yang dilakukan dengan aplikasi ini dapat direkam secara langsung sehingga dapat disimpan dan disaksikan dilain waktu. Dalam Zoom dapat berkomunikasi lebih dari dua orang dengan media sebuah Room (ruangan) yang digunakan untuk melakukan rapatrapat, perkuliahan, seminar online, dan lainnya. Room (ruangan) pada Zoom tersebut dibuat oleh seorang host dan dapat diberlakukan pengimputa kata sandi bagi seseorang yang ingin memasukin ruangan tersebut. Jadi tidak sembarangan orang dapat memasukin ruangan tersebut terkecuali orang-orang yang memang diundang dan beritahukan mengenai kata sandi ruangan tersebut.

Perkembangan yang terjadi dalam transaksi elektronik semakin pesatnya, maka profesi Notaris merupakan seorang pejabat umum yang senantiasa melayani masyarakat, juga diharapkan dapat mengikuti dan tidak tertinggal dalam menyikapi perkembangan tersebut secara tepat. ${ }^{4}$ Dalam dunia kenotarisan juga tidak luput dengan kemajuan teknologi tersebut. Undang-Undang Nomor 11 Tahun 2018 tentang Informasi dan Transaksi Elektornik membuat wacana cyber notary kian bergulir. Selain itu dalam ketentuan Pasal 15 ayat (3) Undang-Undang Nomor 2 Tahun 2014 tentang perubahan atas Undang-Undang Nomor 20 Tahun 2004 Tentang Peraturan jabatan Notaris (UUJN-

\footnotetext{
${ }^{3}$ Nurita, E. (2012). Cyber Notary Pemahaman Awal Dalam Konsep Pemikiran. Bandung: Refika Aditama. h. 53

${ }^{4}$ Hapsari, N. O. M., \& Darori, I. (2017). Peran Notaris Dalam Upaya Perlindungan Hukum Terhadap Pembeli Dalam Jual Beli Online. Repertorium, 4(1). h. 159
} 
P) menyatakan bahwa "selain kewenangan sebagaimana dimaksud pada ayat (10) dan ayat (2), notaris mempunyai kewenangan lain yang diatur dalam Peraturan PerundangUndangan". Dalam penjelasan pasal 15 ayat (3) tersebut dinyatakan "kewenangan lain yang diatur dalam peraturan perundang-undangan yaitu antara lain kwenangan mensertifikasi transaksi yang dilakukan secara elektronik (cyber notary), membuat akta ikrar wakaf dan hipotek pesawat terbang".

Mengacu terhadap hal tersebut apabila dihubungkan dengan pembuatan Akta Notaris yang sering kita jumpai. Praktek cyber notary tersebut sangatlah membantu pekerjaan seorang notaris dalam hal pembuatan akta. Dengan media Konferensi tersebut tidak adanya hambatan jarak dan waktu sehingga dapat mengefisienkan waktu. Penerapan cyber notary ini dikatakan sebuah keniscayaan, dalam menghadapi persaingan perkembangan global, pergeseran pada peran notaris yang berkaitan dengan kewenangan dan tugasnya menuju era cyber notary memanglah tidaklah mudah, dimana notaris sendiri harus siap menyambut era globalisasi dengan perkembangan elektronik yang ada dimana konsep ini disebut juga dengan notary by digital yang akan merambah dan berkembang masuk ke Indonesia. ${ }^{5}$ Penerapan teknologi informasi dalam peresmian akta notaris berdasarkan dengan cyber notary merupakan "sebuah konsep dimana notaris dapat bekerja dengan perkembangan yang ada berbasis teknologi yaitu cyber notary yang merupakan notary public dengan melakukan sebuah pelayanan dengan jasajasa notaris dokumen dengan secara elektronik" ${ }^{6}$ Konsep ini lahir dikarenakan terdapat teknologi-teknologi baru seiring dengan perkembangan jaman yang dapat mempengaruhi pekerjaan notaris terutama dalam hal efisiensi waktu. Teknologiteknologi tersebut antara lain tanda tangan digital (digital signature) dan video conference. ${ }^{7}$

Peresmian akta apabila dilakukan dengan media Konferensi Zoom tersebut belum dapat dibenarkan legalitas atau keabsahannya oleh undang-undang maupun peraturan perundang-undangan yang berlaku. Karena apabila mengacu pada Pasal 1 angka (7) UUJN-P bahwa "Akta Notaris yang selanjutnya disebut akta adalah akta autentik yang dibuat oleh atau dihadapan notaris menurut bentuk dan tata cara yang ditetapkan dalam Undang-Undang ini" selain itu dalam Pasal 16 ayat (1) huruf m UUJN-P menyatakan "bahwa notaris harus membacakan akta dihadapan penghadap". Terlihat disini ketidakjelasan kata "dihadapan" pada pasal-pasal tersebut apakah dihadapan tersebut harus dengan berhadapan secara langsung di kantor notaris ataukah diperbolehkan untuk berhadapan secara virtual melalui media konferensi elektronik.

Berdasarkan latar belakang tersebut maka menarik untuk diketahui dan penulis mengangkat tulisan ini dengan berjudulkan "Legalitas Peresmian Akta Notaris Berbasis Cyber Notary Melalui Media Konferensi Zoom"

Berdasarkan penjelasan diatas dapat ditarik dua permasalahan yang perlu dikemukakan dalam penulisan jurnal ini adalah bagaimana legalitas peresmian akta notaris berbasis

\footnotetext{
${ }^{5}$ Wijanarko, F. R., Mulyoto, M., \& Supanto, S. (2015). Tinjauan Yuridis Akta Notaris Terhadap Pemberlakuan Cyber Notary Di Indonesia Menurut Undang-undang Nomor 2 Tahun 2014 (Doctoral dissertation, Sebelas Maret University). h. 9

${ }^{6}$ Ibid, h. 20

7 Alwajdi, M. F. (2020). Urgensi Pengaturan Cyber Notary Dalam Mendukung Kemudahan Berusaha Di Indonesia. Jurnal Rechts Vinding: Media Pembinaan Hukum Nasional, 9(2), 257. h. 258
} 
cyber notary melalui media konferensi Zoom ? dan akibat hukum peresmian akta notaris berbasis cyber notary melalui media konferensi Zoom ?. Penulisan penelitian ini bertujuan untuk mengetahui legalitas peresmian akta notaris berbasis cyber notary melalui media Konferensi Zoom dan akibat hukum peresmian akta notaris dilakukan dengan media Konferensi Zoom.

Penulisan ini dibuat dengan menuangkan berbagai pemikiran-pemikiran yang baru dan orisinil yang dapat membantu kemajuan dalam dunia pendidikan, walaupun telah ditemukan tulisan-tulisan yang mirip atau serupa dengan tulisan yang ada lebih dahulu. namun tulisan ini tetap memiliki suatu unsur-unsur pembaruan yang terdapat didalamnya. Tulisan ini menggunakan 2 (dua) tulisan terdahulu yang menjadi bahan perbandingannya yaitu antara lain :

1. Jurnal ditulis Zaitunatun Rossalina, diterbitkan oleh Fakultas Hukum Universitas Brawijaya, Tahun 2016. Judul " Keabsahan Akta Notaris Yang Menggunakan Cyber Notary Sebagai Akta Otentik." Dengan permasalahan yaitu "mengenai keabsahan akta notaris yang menggunakan cyber notary sebagai akta otentik."

2. Jurnal ditulis oleh Kadek Setia Dewi dan I Made Hendra Wijaya, diterbitkan oleh Fakultas Hukum Universitas Mahasaraswati Denpasar. Judul “Legalitas Akta Notaris Berbasis Cyber Notary Sebagai Akta Otentik". Permasalahan yang diangkat yaitu mengenai "sertifikasi transaksi yang dilakukan berbasis cyber notary sah sebagai akta otentik." 9

\section{Metode Penelitian}

Metode Penelitian ialah merupakan suatu kegiatan atau cara-cara yang harus dilakukan secara sistematis yang berkaitan dengan kontruksi dan analisa sesuatu yang hendak diteliti dan tentunya dilakukan dengan cara yang konsisten. Penelitian ini menggunakan penelitian normatif. Penelitian dilakukan dengan cara melakukan penelitian menkaji norma hukum itu sendiri dengan asas, kaidah, undang-undang dan peraturan perundang-undangan. Serta pendapat-pendapat para ahli ditambah juga dengan studi kepustakaan dari berbagai buku, jurnal, atau pernyataan-pernyataan para ahli. Pendekatan yang dilakukan dengan pendekatan konsep hukum dan pendekatan perundang-undangan.

Penelitian ini dengan menggunakan bahan hukum primer terdiri dari undang-undang serta peraturan perundang-undangan yang berhubungan dan berkaitan dengan topik pembahasan, serta menggunakan bahan hukum sekunder ialah berupa bahan-bahan hukum seperti literature-literatur dan buku-buku terkait yang ada hubunganya serta doktrin-doktrin para ahli guna mendukung pembahasan pada permasalahan yang ada. Selain itu bahan-bahan hukum yang digunakan juga pada jurnal-jurnal hukum yang telah diterbitkan jadi dapat dipertanggung jawabkan hasil penelitiannya.

\footnotetext{
8 Rossalina, Z. (2016). Keabsahan Akta Notaris Yang Menggunakan Cyber Notary Sebagai Akta Otentik. Kumpulan Jurnal Mahasiswa Fakultas Hukum.

${ }^{9}$ Setiadewi, K., \& Wijaya, I. M. H. (2020). Legalitas Akta Notaris Berbasis Cyber Notary Sebagai Akta Otentik. Jurnal Komunikasi Hukum (JKH), 6(1), 126-134.
} 


\section{Hasil Dan Pembahasan}

\subsection{Legalitas Peresmian Akta Notaris Berbasis Cyber Notary Melalui Media Konferensi Zoom}

Menurut Law Wrence Leff cyber notary itu merupakan ialah "seseorang yang dengan mempunyai kemampuan bidang spesialisasi dalam hal bidang hukum dan computer dimana cyber notary tersebut merupakan sebuah konsep yang dapat memanfaatkan kemajuan teknologi yang ada dalam hal menjalankan tugas dan kewenangan notaris". ${ }^{10}$ Dalam transaksi yang dilaksanakan dengan cara elektronik (berbasis cyber notary) tidak adanya pertemuan (face to face) yang dilakukan secara tatap muka oleh para pihak, sehingga penggunaan media telekomunikaasi dalam suatu transaksi dikatakan akan memberikan keefektifan dan keefisienan tersendiri tanpa adanya hambatan ruang dan waktu bagi para pihak yang melangsungkan transaksinya sebagaimana dengan transaksi yang sering dijumpai dengan cara biasa atau kovensional. ${ }^{11}$

Notaris pada saat menjalankan tugas jabatannya tidak luput dengan perkembangan teknologi yang ada. "Dalam Pasal 15 ayat (3) Undang-Undang Nomor 2 Tahun 2014 tentang perubahan atas Undang-Undang Nomor 20 Tahun 2004 Tentang Peraturan jabatan Notaris (UUJN-P) menyatakan bahwa kewenangan sebagaimana dimaksud pada ayat (10) dan ayat (2), notaris mempunyai kewenangan lain yang diatur dalam Peraturan Perundang-Undangan".

Kewenangan lain yang disebutkan dalam Pasal 15 ayat (3) dijelaskan lebih lanjut dalam penjelasan pasal 15 ayat (3) tersebut dinyatakan "kewenangan lain yang diatur dalam peraturan perundang-undangan yaitu antara lain kwenangan mensertifikasi transaksi yang dilakukan secara elektronik (cyber notary), membuat akta ikrar wakaf dan hipotek pesawat terbang". Kewenangan yang dimiliki notaris dalam hal mensertifikasi sebuah transaksi yang dilakukan dengan cara elektronik (cyber notary). Sertifikasi dalam bahasa inggris yang memiliki arti keterangan atau pengesahan selain itu juga dapat dikatakan sebagai sebuah prosedur dari pihak ketiga yang memberikan suatu jaminan tertulis baik dalam proses, produknya maupun jasa-jasa yang telah sesuai dan memenuhi standarstandar berdasarkan audit yang dilaksanakan dengan prosedur-prosedur yang telah disepakati. Kewenangan-kewenangan notaris dalam mensertifikasi transaksi dilakukan dengan cara elektronik (cyber notary). Sertifikasi ini bermula atau berasal dari bahasa inggris "Certification" yang merupakan berarti keterangan dan ataupun pengesahan, sertifikasi itu sendiri merupakan sebuah prosedur dalam hal pihak ketiga dapat memberikan sebuah jaminan tertulis bahwa dalam suatu prosesnya produk atas jasajasa tersebut telah dapat memenuhi standar-standar yang ditentukan berdasarkan dengan audit yang dilakukan dengan prosedur-prosedur yang disepakati sebelumnya. Kewenangan Notaris dalam pasal 15 ayat (3) UUJNP mengenai sertifikasi transaksi yang dilakukan dengan cara elektronik (cyber notary) bertujuan agar menjamin adanya ketertiban, kepastian serta perlindungan hukum kepada masyarakat terhadap adanya kemajuan teknologi serta dengan dibutuhkannya suatu alat bukti yang memiliki sifat

10 Rositawati, D., Utama, I. M. A., \& Kasih, D. P. D. (2017). Penyimpanan Protokol Notaris secara Elektronik dalam Kaitan Cyber Notary. Acta Comitas: Jurnal Hukum Kenotariatan, 2(2), 172-182. h. 175

${ }^{11}$ Widiasih, N. K. A. E. A Kewenangan Notaris dalam Mensertifikasi Transaksi yang Dilakukan Secara Elektronik (Cyber Notary). Acta Comitas: Jurnal Hukum Kenotariatan, 5(1), 150-160. h. 156 
autentik mengenai perbuatannya, penetapan, perjanjian dan peristiwa hukum yang di buat oleh pejabat yang berwenang. ${ }^{12}$

Namun apabila mengacu dalam Pasal 1 angka (7) UUJN-P bahwa "Akta Notaris yang selanjutnya disebut akta adalah akta autentik yang dibuat oleh atau dihadapan notaris menurut bentuk dan tata cara yang ditetapkan dalam Undang-Undang ini" selain itu dalam Pasal 16 ayat (1) huruf m UUJN-P menyatakan bahwa "notaris harus membacakan akta dihadapan penghadap dengan dihadiri oleh paling sedikit 2 (dua) orang saksi, atau 4 (empat) orang saksi khusus untuk pembuatan Akta wasiat dibawah tangan, dan ditandatangani pada saat itu juga oleh penghadap, saksi, dan Notaris". Pasal 16 yang memuat unsur-unsur mengenai keotentikan sebuah akta yang telah ditentukan dalam Pasal 1868 KUHPerdata bahwa "Suatu akta otentik ialah suatu akta yang dibuat dalam bentuk yang telah ditentukan undang-undang oleh atau dihadapan pejabat umum yang berwenang untuk itu di tempat akta itu dibuat". Karena "kekuatan pada akta notaris itu sendiri sebagai alat bukti terletak pada kekhasan karakter pembuatnya dimana dalam hal seorang notaris yang ditunjuk langsung oleh undangundang sebagai pejabat umum yang diberikan sebuah wewenang untuk membuat sebuah akta". 13

Apabila dilihat dalam Pasal 15 ayat (3) menimbulkan kekaburan norma dimana Pasal 15 tersebut menjelaskan kewenangan yang dimiliki oleh notaris dalam melaksanakan terhadap sertifikasi transaksi dengan cara elektronik (cyber notary). Pasal 15 itu sendiri memberikan kewenangan dalam melaksanakan sertifikasi transaksi kepada Notaris yang dilakukan dengan secara elektronik (cyber notary) tetapi tidak dijelaskan lebih lanjut apakah dalam cyber notary ini para penghadap harus hadir berhadapan secara langsung/fisik di kantor notaris ataukah dihadapan masing-masing para pihak walaupun tidak langsung di kantor notaris tetapi berhadapan secara virtual dengan media Konferensi yang dapat diperbolehkan. Karena dalam hal cyber notary penghadap berada dikediaman masing-masing dan tidak secara langsung hadir di kantor notaris berhadapan dengan notaris tetapi melalui media Konferensi Zoom.

Pengesahan akta notaris yang dilakukan melalui media Konferensi Zoom sebenarnya dapat dikatakan cukup aman karena Room (ruangan) yang digunakan bersama para pihak yang berkepentingan dapat diisikan sebuah kata sandi sehingga tidak dapat dimasuki dan diikuti oleh orang-orang yang tidak memiliki keperluan dalam hal tersebut, selain itu seluruh video dan percakapan di Zoom juga dapat direkam sehingga dapat disimpan dan dilihat lain waktu. Namun memiliki celah kerugian apabila disalahgunakan oleh para pihak apabila dalam suatu ketika terjadi sengketa pihak tersebut bisa saja memungkiri terhadap adanya proses pembacaan akta itu yang tidak dilakukan dengan berhadapan langsung atau benar-benar menghadap yaitu hadir langsung di kantor notaris dan berhadapan langsung dengan notaris.

Penyelesaian kabur norma pada Pasal 15 ayat 3 mengenai sertifikasi elektronik (cyber notary) adalah dengan menginterpretasikan dengan mengetahui pendapat-pendapat

12 Bahri, S., Yahanan, A., \& Trisaka, A. (2019). Kewenangan Notaris Dalam Mensertifikasi Transaksi Elektronik dalam rangka Cyber Notary. Repertorium: Jurnal Ilmiah Hukum Kenotariatan, 142-157. h. 146

${ }^{13}$ Sjaifurrachman. (2011). Aspek Pertanggungjawaban Notaris Dalam Pembuatan Akta. Bandung: Mandar Maju. h. 5 
dari para sarjana yang berkaitan mengenai konsep transaksi elektronik (cyber notary) itu sendiri. Konsep mengenai cyber notary sesungguhnya pertemuan fisik tidaklah mutlak dimana konsep ini justru dirasa dapat menghilangkan mengenai aspek pertemuan fisik para pihak terhadap notaris itu sendiri, tetapi tetap sesuai koridor hukum, Jadi di dalam perubahan UUJN nanti hendaknya dapat dicantumkan selain yang dengan cara konvensional dapat juga dilakukan dengan secara dunia elektronik/cyber. Rosa dan Lolly meyebutkan "tidak menampik konsep cyber notary dapat diterapkan di Indonesia yaitu dengan penghilangan klausul (di hadapan dan dibacakan oleh notaris) bukan tidak mungkin akan dilakukan dengan mengubah klausul dihadapan dan membacakan serta berharap usulan revisi UUJN dapat segera dilakukan, sebab menurut Lolly konsep cyber notary ini merupakan terobosan baru dalam hukum Indonesia sehingga harus segera diakomodir, sebab kemajuan teknologi itu tidak bisa dibendung lagi" ${ }^{14}$ Edmon Makarim menyebutkan "kata dihadapan dalam Pasal 1868 KUHPerdata apabila dikaitkan dengan konsep cyber notary membahas pengidentikan pembuatan akta akan selalu dilakukan dengan media teleconference, namun menurut Edmon sesungguhnya cyber notary memilik prinsip yang sama dengan Notaris secara konvensional bahwa para penghadap tetap datang ke kantor notaris dan selanjutnya membaca draft akta pada masing-masing computer dan apabila telah sepakat lalu para penghadap menandatanganinya dengan cara elektronik". ${ }^{15}$

Dengan demikian, peresmian akta apabila dilakukan dengan media Konferensi Zoom tersebut belum dapat dibenarkan legalitas atau keabsahannya oleh undang-undang maupun peraturan perundang-undangan yang berlaku. Karena apabila mengacu pada Pasal 1 angka (7) UUJN-P bahwa "Akta Notaris yang selanjutnya disebut akta adalah akta autentik yang dibuat oleh atau dihadapan notaris menurut bentuk dan tata cara yang ditetapkan dalam Undang-Undang ini" selain itu dalam Pasal 16 ayat (1) huruf m UUJN-P menyatakan "bahwa notaris harus membacakan akta dihadapan penghadap". Terlihat disini apabila dihubungkan dengan kabur norma pada Pasal 15 ayat 3 mengenai transaksi elektronik (cyber notary) tidak menjelaskan lebih lanjut mengenai para pihak yang menghadap hadir secara fisik dikantor Notaris dengan dibacakan langsung oleh Notaris atau boleh tidak hadir secara fisik melainkan hadir dihadapan Notaris namun secara virtual/via elektronik dengan menggunakan media konferensi yang telah diperbolehkan dan apabila mengacu pada konsep cyber notary yang dijelaskan oleh Edmon Makarim bahwasanya dalam cyber notary ini para penghadap tetap hadir secara fisik dikantor Notaris dengan membaca draft akta pada media elektronik yang sudah disiapkan dan apabila telah dirasa disepakati lalu para penghadap langsung menandatanganinya dengan cara elektronik.

\subsection{Akibat Hukum Peresmian Akta Notaris Berbasis Cyber Notary Melalui Media Konferensi Zoom}

Mengenai pembuatan akta pasti selalu berkaitan dengan Pasal 1868 KUHPerdata yang menjelaskan syarat otentisitas akta yang menyatakan "bahwa akta notaris wajib tersebut dibuat dalam bentuk yang telah ditentukan oleh undang-undang dan akta dibuat oleh atau dibuat dihadapan pejabat umum yang berwenang di tempat dimana akta tersebut

\footnotetext{
${ }^{14}$ Nurita, E. Opcit h. 49

15 https://notarymagazine.com/akankah-terjadi-disrupsi-bagi-jasa-notaris/. Diakses 1 Maret 2021, pukul 11.53 WITA
} 
dibuat". Jadi dikatakan akta tersebut dapat dikatakan autentik apabila dibuat oleh pejabat yang berwenang ditempat akta tersebut dibuat sesuai bentuk yang telah ditentukan oleh undang-undang sehingga dengan begitu sebuah akta baru dapat dikatakan otentik.

Dalam "Pasal 16 ayat (1) huruf m UUJN-P menyatakan bahwa notaris harus membacakan akta dihadapan penghadap dengan dihadiri oleh paling sedikit 2 (dua) orang saksi, atau 4 (empat) orang saksi khusus untuk pembuatan Akta wasiat dibawah tangan, dan ditandatangani pada saat itu juga oleh penghadap, saksi, dan Notaris". Dalam Penjelasan Pasal 16 ayat (1) huruf m dijelaskan "bahwa notaris harus hadir secara fisik dan menandatangani Akta dihadapan penghadap dan sanksi". Dapat diartikan hadir secara fisik bahwa fisiknya hadir secara langsung, hadir artinya ada atau datang. ${ }^{16}$ Apabila dikaitkan dengan konsep cyber notary yang terdapat dalam Undang-Undang Nomor 2 Tahun 2014 dengan kemajuan perkembangan teknologi sehingga dapat bisa mempertemukan antara dua belah pihak ataupun lebih dengan di tempat yang berbeda dengan adanya fasilitas voice/suara dan video yang sesuai dengan keadaan langsung dan senyatanya dengan kondisi dan tempat dikediaman masing-masing.

Namun dengan adanya Pasal 16 ayat (1) huruf UUJN-P ini yang akhirnya membatasi kinerja notaris dalam hal konsep cyber notary itu sendiri, padahal seharusnya notaris juga harus mengikuti dan memanfaatkan kemajuan teknologi yang ada sehingga dapat mempermudah tugas-tugasnya dalam hal menjalankan jabatannya dan diharapkan dapat meningkatkan jasa yang akan diberikan kepada masyarakat.

Apabila konsep cyber notary ini dalam peresmian akta dirasa perlunya ada pengaturan yang mengatur dengan jelas bagaimana ketentuan atau syarat dalam peresmian akta otentik/notaris yang dilakukan dengan menggunakan konsep cyber notary salah satunya adalah media Konferensi Zoom. Sehingga dirasa perlunya pembaruan dalam UUJN-P khusus yang berkaitan dengan proses peresmian akta berbasis secara elektronik. Jadi dalam saat menjalankan dan melaksanakan tugas jabatannya seorang notaris dirasa harus dapat menggunakan dan mengikuti perkembangan teknologi yang ada dalam menjalankan pekerjaannya tanpa harus melanggar undang-undang dan ketentuanketentuan yang telah ditetapkan.

Menurut hemat penulis rasanya apabila hanya pembacaan akta yang dilakukan melalui media Konferensi Zoom dirasa tidak mempengaruhi akan bentuk akta sebagaimana yang telah ditentukan pada Pasal 38 UUJN-P. Meskipun bahkan penandatanganannya dilakukan secara elektronik dengan bentuk akta tersebut akan tetap keluar dalam sebagai akta tertulis (paper based). G.H.S Lumban Tobing menyebutkan "seorang notaris apabila dalam melaksanakan pada pembacaan dari akta itu, para pihak/penghadap dirasakan pada satu pihak dapat memiliki sebuah jaminan apabila suatu hal mereka telah menandatangani mengenai hal-hal apa-apa saja yang telah dengan sebelumnya (pada saat pembacaan dilakukan oleh notaris) dan apabila dilihat dari dipihak lain diamana para penghadap dan notaris itu sendiri dapat memperoleh suatu keyakinan

16 Soeroso, R. (2010). Perjanjian Di Bawah Tangan. Jakarta: Sinar Grafika. h. 24 
bahwasanya jika akta tersebut memang benar-benar pada isinya berisikan mengenai apa yang telah diketahui dan dikehendaki oleh para penghadap itu sendiri" ${ }^{17}$

Pembacaan akta yang dilaksanakan oleh seorang notaris yang mengacu kepada suatu kewajiban dalam sebuah proses pembuatan akta otentik. Dalam Pasal 16 ayat (1) huruf $m$ UUNJ-P dikatakan proses pembacaan akta merupakan suatu peresmian pembacaan dan dilanjutkan penandatanganan terhadap akta yang dikenhendaki oleh para pihak. Dalam pembuatan akta notaris apabila dilihat dari sisi fungsi akta otentik itu sendiri bahwa pembacaan akta ialah hal wajib untuk dilakukannya oleh setiap notaris dalamhal menjalankan setiap tugasnya terkait akta. Mengenai pembacaan akta memiliki beberapa manfaat menurut Tan Thong Kie yaitu sebagai berikut :18

1. Pada Saat Peresmian (verlijden) yakni akta tersebut akan berakhir,terdapat adanya kesempatan dalam hal memperbaiki apabila terdapat adanya sebuah kesalahan seperti hal penulisan kalimat/kata-kata yang terdapat sebelumnya mungkin tidak diketahui atau tidak adanya tampak karena adanya kemungkinan bisa saja adanya terdapat sebuah kesalahan fatal.

2. Diberikannya kesempatan kepada para pihak/penghadap apabila dirasa terdapat hal-hal yang kurang dimengerti, membingungkan, kurang jelas atapun hal yang bersifat ambigu dari isi akta ditulis/dibacakan tersebut.

3. Terdapat kesempatan terhadap Notaris dan para pihak pada saat detik-detik terakhir yang sebelum akta itu telah selesai di tandatangani oleh para pihak maupun notaris dimana dapat mengadakan sebuah pemikiran ulang yakni mengenai isi akta tersebut apabila terdapat memiliki keinginan bertanya maupun ingin mengubah akta tersebut.

Apabila dalam hal pembacaan akta tersebut tidak dilakukan notaris maka dalam hal sesuai dengan "Pasal 16 ayat (9) UUJN bahwa Jika salah satu syarat sebagaimana dimaksud dalam ayat (1) huruf $\mathrm{m}$ dan ayat (7) tidak dipenuhi, maka Akta yang bersangkutan hanya mempunyai kekuatan pembuktian sebagai akta di bawah tangan".

Selain itu apabila penandatanganan dilakukan dalam proses peresmian akta berbasis cyber notary ini berarti para pihak hadir dihadapan notaris ditempat kediaman masingmasing dengan menggunakan media Konferensi salah satunya Zoom. Pembacaan akta tersebut dilakukan dihadapan para pihak dimana dalam pembacaan akta tersebut semua pihak yang berkepentingan baik para pihak, notaris dan saksi-saksi semuanya menggunakan media Konferensi salah satunya Zoom. Dimana semua pihak ini masuk ke dalam Room (ruangan) yang telah dibuat oleh pihak notaris dalam pada waktu yang telah ditentukan dan bersamaan, setelah akta itu dibacakan secara langsung, selanjutnya para pihak/penghadap telah memahami dari isi akta tersebut maka selanjutnya akta ditandatangani oleh para pihak, notaris dan saksi-saksi. Tandatangan yang mereka lakukan dalam hal ini dengan dilakukannya menggunakan tanda tangan

\footnotetext{
17 Rossalina, Z. (2016). Keabsahan Akta Notaris Yang Menggunakan Cyber Notary Sebagai Akta Otentik. Kumpulan Jurnal Mahasiswa Fakultas Hukum. h. 13

${ }^{18}$ Ibid. h. 14
} 
digital. Dalam hal tanda tangan digital ini terdapat beberapa tahapan-tahapan yang sebagai berikut : 19

1. Pertama, "Dalam hal proses pembentukan pada tanda tangan digital ini dengan menggunakan model semacam sidik jari yang dapat dihasilkan dari sebuah dokumen-dokumen dan kunci privat serta verifikasi tanda tangan digital adalah proses dalam hal melakukan pengecekan tanda tangan digital tersebut dengan melakukan mereferensikan ke dokumen asli dan pada kunci publik yang sebelumnya telah diberikan, sehingga ditentukan dapat apakah tanda tangan digital itu yang telah dibuat untuk dokumen yang sama yang dengan menggunakan kunci privat".

2. Kedua, "Apabila dalam proses yang dilakukan tersebut dapat telah dapat terpenuhi sesuai dengan yang ditentukan maka suatu tanda tangan digital tersebut agar dapat memenuhi unsur-unsur yuridis seperti halnya yang tertuang di dalam sebuah tanda tangan secara manual (konvensional). Tanda tangan yang dibubuhkan secara digital itu dianggap dapat mengakui bahwa semua hal yang telah ditulisnya tersebut pada dokumen-dokumen elektronik yang bersangkutan. Jadi tanda tangan digital tersebut memiliki sifat "one signature document" yang dimana apabila terdapat terjadi suatu perubahan-perubahan sedikit saja yang terdapat pada tulisan yang dikirim tersebut maka tanda tangan digital itu juga akan berubah dan selanjutnya akan dinyatakan menjadi tidak valid".

"Tanda tangan elektronik yang dapat dikatakan sah apabila tanda tangan tersebut berupa sebuah suatu bentuk rangkaian kode (bukan merupakan gambar sebuah tanda tangan ataupun hasil scanan ) yang juga harus dapat memenuhi 6 (enam) hal syaratsyarat minimum dan dalam Pasal 11 UU ITE serta ditambah dengan 1 (satu) pengaman dengan memenuhi 3 (tiga) minimum dalam Pasal 12 UU ITE sehingga dapat memberikam sebuah pengakuan dengan secara tegas dan benar bahwa meskipun dikatakan hanya sebuah kode, tetapi tanda tangan elektronik itu dapat memiliki sebuah kedudukan sama halnya dengan sebuah tanda tangan dengan cara manual (yang dibuat secara konvensional) seperti pada umumnya dapat memiliki kekuatan hukum maupun akibat hukum" ${ }^{20}$

Apabila dikaitkan dengan kabur norma pada Pasal 15 ayat 3 mengenai transaksi elektronik (cyber notary) mengakibatkan ketidakpastian dalam penerapannya karena tidak dijelaskan lebih lanjut mengenai bagaimana para penghadap dalam peresmian sebuah akta dari sistem pembacaan draft akta sampai penandatanganannya, sehingga perlunya ada pengaturan yang mengatur dengan jelas bagaimana ketentuan atau syarat dalam pembuatan akta notaris yang dilakukan dengan konsep (cyber notary) salah satunya dengan menggunakan media Konferensi Zoom. Sehingga dirasa perlunya pembaruan dalam UUJN-P, khusus yang berkaitan dalam hal pembuatan akta berbasis secara elektronik sehingga tidak menimbulkan kekaburan dan dapat memberikan kepastian hukum mengenai konsep cyber notary.

19 Matra, A. F. (2012). Penerapan Cyber Notary di Indonesia Ditinjau dari Undang-Undang Nomor 30 Tahun 2004 tentang Jabatan Notaris. Depok: Tesis Magister Kenotariatan FH UI. h. 54 ${ }^{20}$ Mira Nila Kusuma Dewi. (2016). Kedudukan Hukum Akta Risalah Rapat Umum Pemegang Saham (RUPS) Melalui Media Elektronik. Universitas Indonesia Timur. Makasar. Vol. 9 No.1. h. 112-1131 


\section{Kesimpulan}

Berdasarkan hasil pembahasan yang dijelaskan dan dipaparkan diatas, maka diperoleh sebuah kesimpulan bahwa peresmian akta apabila dilakukan dengan media Konferensi Zoom tersebut belum dapat dibenarkan legalitas atau keabsahannya. Karena apabila mengacu pada Pasal 1 angka (7) UUJN-P bahwa "Akta Notaris yang selanjutnya disebut akta adalah akta autentik yang dibuat oleh atau dihadapan notaris menurut bentuk dan tata cara yang ditetapkan dalam Undang-Undang ini" selain itu dalam Pasal 16 ayat (1) huruf $\mathrm{m}$ UUJN-P menyatakan "bahwa notaris harus membacakan akta dihadapan penghadap". Terlihat disini apabila dihubungkan dengan kabur norma pada Pasal 15 ayat 3 mengenai transaksi elektronik (cyber notary) tidak menjelaskan lebih lanjut mengenai transaksi elektronik (cyber notary) sehingga akibat hukum yang ditumbulkan ialah ketidakpastian dalam penerapannya karena tidak dijelaskan lebih lanjut mengenai bagaimana para penghadap dalam peresmian sebuah akta para pihak yang harus menghadap secara fisik dikantor Notaris atau boleh hadir dihadapan Notaris namun secara virtual atau via elektronik dengan menggunakan media konferensi yang telah diperbolehkan. Sehingga perlunya ada pengaturan yang mengatur dengan jelas bagaimana ketentuan atau syarat dalam pembuatan akta notaris yang dilakukan dengan konsep (cyber notary) salah satunya dengan menggunakan media Konferensi Zoom. Sehingga dirasa perlunya pembaruan dalam UUJN-P khusus yang berkaitan dengan proses pembuatan akta berbasis secara elektronik sehingga tidak menimbulkan kekaburan dan dapat memberikan kepastian hukum mengenai konsep cyber notary.

\section{Daftar Pustaka}

\section{BUKU:}

Makarim, E. (2013). Notaris dan Transaksi Elektronik; Kajian Hukum Tentang Cyber Notary atau Electronic Notary. Jakarta: PT Raja Grafindo Perkasa.

Nurita, E. (2012). Cyber Notary Pemahaman Awal Dalam Konsep Pemikiran. Bandung: Refika Aditama.

Soeroso, R. (2010). Perjanjian Di Bawah Tangan. Jakarta: Sinar Grafika.

Sjaifurrachman. (2011). Aspek Pertanggungjawaban Notaris Dalam Pembuatan Akta. Bandung: Mandar Maju

\section{Jurnal:}

Alwajdi, M. F. (2020). Urgensi Pengaturan Cyber Notary Dalam Mendukung Kemudahan Berusaha Di Indonesia. Jurnal Rechts Vinding: Media Pembinaan Hukum Nasional, 9(2), 257.

Bahri, S., Yahanan, A., \& Trisaka, A. (2019). Kewenangan Notaris Dalam Mensertifikasi Transaksi Elektronik dalam rangka Cyber Notary. Repertorium: Jurnal Ilmiah Hukum Kenotariatan, 142-157 
Hapsari, N. O. M., \& Darori, I. (2017). Peran Notaris Dalam Upaya Perlindungan Hukum Terhadap Pembeli Dalam Jual Beli Online. Repertorium, 4(1).

Matra, A. F. (2012). Penerapan Cyber Notary di Indonesia Ditinjau dari UndangUndang Nomor 30 Tahun 2004 tentang Jabatan Notaris. Depok: Tesis Magister Kenotariatan FH UI.

Rossalina, Z. (2016). Keabsahan Akta Notaris Yang Menggunakan Cyber Notary Sebagai Akta Otentik. Kumpulan Jurnal Mahasiswa Fakultas Hukum

Rositawati, D., Utama, I. M. A., \& Kasih, D. P. D. (2017). Penyimpanan Protokol Notaris secara Elektronik dalam Kaitan Cyber Notary. Acta Comitas: Jurnal Hukum Kenotariatan, 2(2), 172-182.

Setiadewi, K., \& Wijaya, I. M. H. (2020). Legalitas Akta Notaris Berbasis Cyber Notary Sebagai Akta Otentik. Jurnal Komunikasi Hukum (JKH), 6(1), 126-134.

Widiasih, N. K. A. E. A Kewenangan Notaris dalam Mensertifikasi Transaksi yang Dilakukan Secara Elektronik (Cyber Notary). Acta Comitas: Jurnal Hukum Kenotariatan, 5(1), 150-160.

Wijanarko, F. R., Mulyoto, M., \& Supanto, S. (2015). Tinjauan Yuridis Akta Notaris Terhadap Pemberlakuan Cyber Notary Di Indonesia Menurut Undang-undang Nomor 2 Tahun 2014 (Doctoral dissertation, Sebelas Maret University).

\section{PERATURAN PERUNDANG-UNDANGAN:}

Kitab Undang-Undang Hukum Perdata, Soedharyo Soimin, 2014, Sinar Grafika, Jakarta

Undang-Undang Nomor 2 Tahun 2014 tentang Peruabahan Atas Undang-Undang Nomor 20 Tahun 2004 Tentang jabatan Notaris

Undang-Undang Nomor 11 Tahun 2018 tentang Informasi dan Transaksi Elektornik

\section{WEBSITE:}

Akankah Terjadi Disrupsi Bagi Jasa Notaris ? di https://notarymagazine.com/akankahterjadi-disrupsi-bagi-jasa-notaris/. Diakses 1 Maret 2021, pukul 11.53 WITA 